\title{
Obituaries
}

Obituaries should be submitted by email to Laura Pacey at I.pacey@nature.com.

All submitted obituaries should be 350 words maximum in length (apart from obituaries for past presidents of the BDA where the length should be $700-800$ words).

Content of the obituary is down to the individual author, and the approval of the family should be given for the obituary prior

to submission to the $B D J$.

\section{(JAMES) RALPH MCCARTHY}

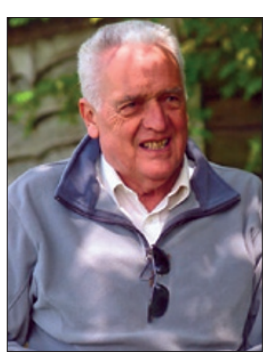

Most people who had anything to do with the Dental Practice Board in the 1970s, 80s and 90s know Ralph McCarthy. Ralph was a general dental practitioner

when appointed Dental Advisor in 1974; but over the years progressed to become Senior Dental Advisor and then Chief Dental Advisor.

Ralph, with his short hair and ready smile, was known for his humour, wisdom and sound judgment. Highly approachable, he advised many a practitioner (and dental advisor) on the detailed side of dental regulations; and as Head of the Monitoring Service, kept an eagle eye on the few practitioners who tried to bend the rules.

Board meetings of the Dental Practice Board were held about half a dozen times a year. After such meetings the members would often proceed to a nearby hostelry. I remember Ralph clutching a pint to his chest, leaning back and regaling the assembled company with tales of the 'colourful' characters he'd had to deal with over the years. This was Ralph in his element.

James Ralph McCarthy was born on 27 August 1930 in Manchester. His father was later to become a noted war correspondent. After qualifying from University College in 1956, he spent a number of years in general dental practice, before moving to Eastbourne and the Dental Practice Board.

Ralph's interests included photography, where he often used a high quality
$5 \times 4$ plate camera - difficult to operate and only for real enthusiasts. On retirement he took up cooking where his exploratory nature lead to rare combinations and a style described by his beloved wife as unique and interesting.

Ralph, who died on 28 May, will be sadly missed by his many friends and former colleagues. Our sympathies go especially to his wife Margaret and his two children, Andrew and Mary Jane.

Mervyn Yewe-Dyer

\section{FLORENCE MESSER}

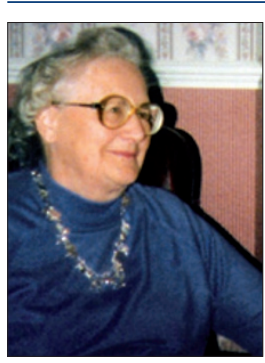

22 November 1915 - 9 May 2013. The membership of the British Dental Association was in the region of 4,500 at the time Florence Messer joined the staff as a shorthand typist, in the Spring of 1934. The circulation of the British Dental Journal was just a few hundred more. Between Miss Messer's arrival and her retirement in 1973, the circulation of the journal rose to 17,000 and tributes at the time of her departure emphasised her role in this success.

Most of Miss Messer's duties from an early date were in the journal department, and she knew and worked with a succession of editors. These included Bryan J. Wood, to whose Kettering home the editorial and management work of the journal was relocated during the Second World War. Miss Messer was accommodated in the family home during this period, and here she undertook every task connected with the production of the $B D J$, except the actual printing. After the war, she effectively combined the roles of journal manager and advertisement manager, and by her ability and application she built up the business side of the $B D J$.

Her dedication to the $B D J$ and BDA was enormous. This included an important contribution to the archives of the association: her account of the history of the British Dental Journal is the definitive source of information on its beginnings and development.

She left an impression of someone of the 'old school' who believed in hard work, standards and unfailing courtesy. Her example was still being set to colleagues today, with any communication to pensioners from the Chief Executive or Trustees always promptly answered with courteous notes of appreciation, all set out in her beautiful handwriting.

Some former members of staff who joined the $B D J$ as teenagers in the early 1960s recall with affection the training and preparation for working life they received from Miss Messer, subsequently maintaining a lifetime correspondence with her. Her niece too has fond memories of a kind and indulgent aunt.

By all accounts Florence Messer avoided the limelight, but she deserves her place in the long history of the $B D J$.

Ian Morley 